\title{
Dent-O-Myths Amid Young Community: A Cross-Sectional Study
}

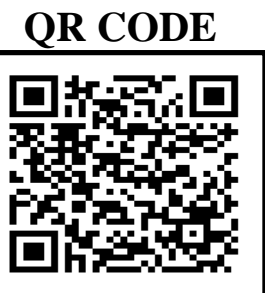

\section{VINITA MARY A. (D ) ${ }^{1}$, KESAVAN R. ${ }^{2}$, KEERTHANA S. *3, KIRUTHIGA G. ${ }^{3}$, KOWSALYA M. ${ }^{3}$, POOJA R. ${ }^{3}$}

INTRODUCTION: The word 'Myth' is derived from the Greek word "Mythos", meaning the stories passed by a group of certain population having a strong impact on seeking general and dental treatment even during illness.

AIM: The aim of this study was to access the prevalence of dental myths among the young population and to interpret their level of knowledge, awareness and perception.

MATERIALS AND METHOD: A cross-sectional questionnaire survey was conducted amongst 500 young population of age between 18-28 years between May to August 2020, COVID-19 pandemic period. A pretested validated questionnaire was formatted on Google forms and circulated in various social media platforms. The collected data was subjected to statistical analysis.

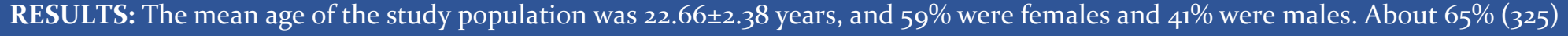
and $56 \%(280)$ of the study subjects believed correctly that mouthwash alone will not maintain oral health and chewing gum will not clean their teeth, respectively. When asked about their responses in case of pain in oral cavity, most people $46 \%$ (230) reported they would visit a dentist and major segment of study subjects $56 \%(281)$ believed that there can be more methods for treating oral pain other than the extraction of the tooth itself.

CONCLUSION: The result of this study revealed that the younger population are more aware and didn't believe much regarding various dental myths.

KEYWORDS: Beliefs, Population, Community

\section{INTRODUCTION}

India has a wide cultural, ethnic, geographical and religious diversity which plays an integral role in shaping the system of individual's beliefs. Culture is represented by the beliefs, values shared by the people and it has its own influence on a person's general perspective of things. ${ }^{1}$ Unfortunately, false beliefs, i.e., myths were handed down to generations to believe and are still held in high esteems in certain population. ${ }^{2}$

The word 'Myth' was derived from the Greek word "Mythos", meaning the stories passed by a group of certain population having a strong impact on seeking general and dental treatment even during illness. ${ }^{3}$ According to Merriam Webster online dictionary, Myth is defined as a popular belief or tradition which has grown up around someone or something. ${ }^{2}$ Dental myths are very common in India. Generally, one's actions are preceded by perceptions. Perception is a process, through which an individual becomes aware, conscious and can process, interpret the information regarding the situation. But this is subjective in nature and can differ from person to person based on different factors. Thus, the same information of a particular situation can be processed differently by two different individuals. ${ }^{4}$ Factors that leads to the evolution of dental myths are socio-cultural factors, blind traditional beliefs, lack of basic education, lack of awareness and non-scientific knowledge. ${ }^{5}$

One's strong belief in myths can turn a simple problem into a chronic disease that may end upon high financial cost treatment because of the lack of knowledge to treat it at an initial stage. ${ }^{3}$ The faith on myths should be eradicated at the bud stage by providing proper education, health care awareness and through advertisements in television, social media and other media outlets etc. The aim of this study was to access the prevalence of dental myths among the present young population to interpret their level of knowledge, awareness and perception.

\section{MATERIALS AND METHOD}

A cross-sectional questionnaire survey was conducted to access the prevalence of various dental-myths 
believed among young population of age between 18-28 years. The study was conducted during the COVID-19 lockdown period. A pretested and validated electronic questionnaire assessing the knowledge, awareness and perception of young adults regarding prevalent dental myths was framed on online filling format using Google forms. Then the link was circulated on various social media platforms such as WhatsApp, Messenger and Instagram, with a note explaining the purpose of the study.

The questionnaire was designed in accordance with the factors believed by people traditionally, mostly with the close-ended questions and a few open-ended questions to offer the subject the opportunity to express his/her views. The study was conducted between $21^{\text {st }}$ May 2020, and $7^{\text {th }}$ August 2020. The participants were asked to complete and submit the responses. It took about 5-7 minutes to complete the survey. Form limiter was used to limit multiple responses from same participant and to limit the data collection up to 500 responses.

The questions were framed to access the knowledge, awareness and perception of dental myths among the young population. Data was analyzed by the t-test using SPSS version 16.0

\section{RESULT}

A descriptive cross-sectional survey was conducted to evaluate the prevalence of dental myths among the young population. The age of the study population ranged from 18-28years (Mean- 22.66; SD+2.38, Figure 1) and 295 (59\%) were females and 205 (41\%) were males (Figure 2).

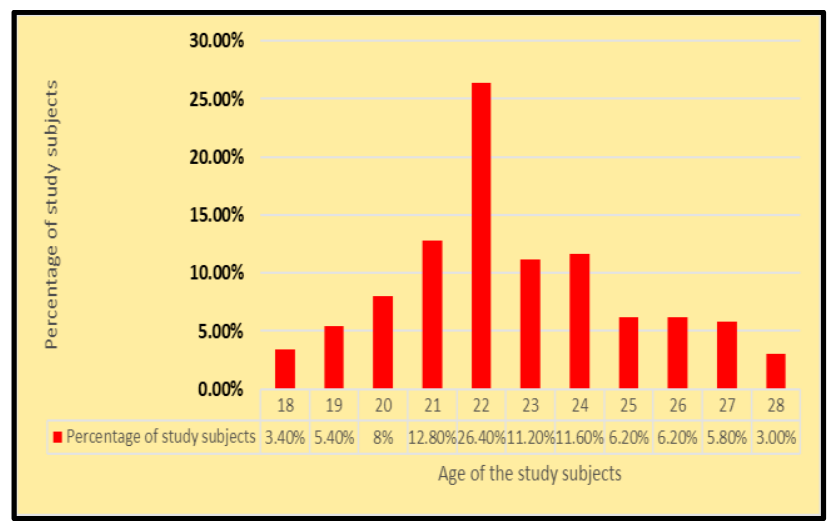

Figure 1. Distribution of study subjects according to age

When questioned about 'brushing pattern and techniques', $67 \%$ (335) considered erroneously that bleeding while brushing was not a important sign for poor gingival health and almost 68\% (343) reported that they would stop brushing if their gums started bleeding.

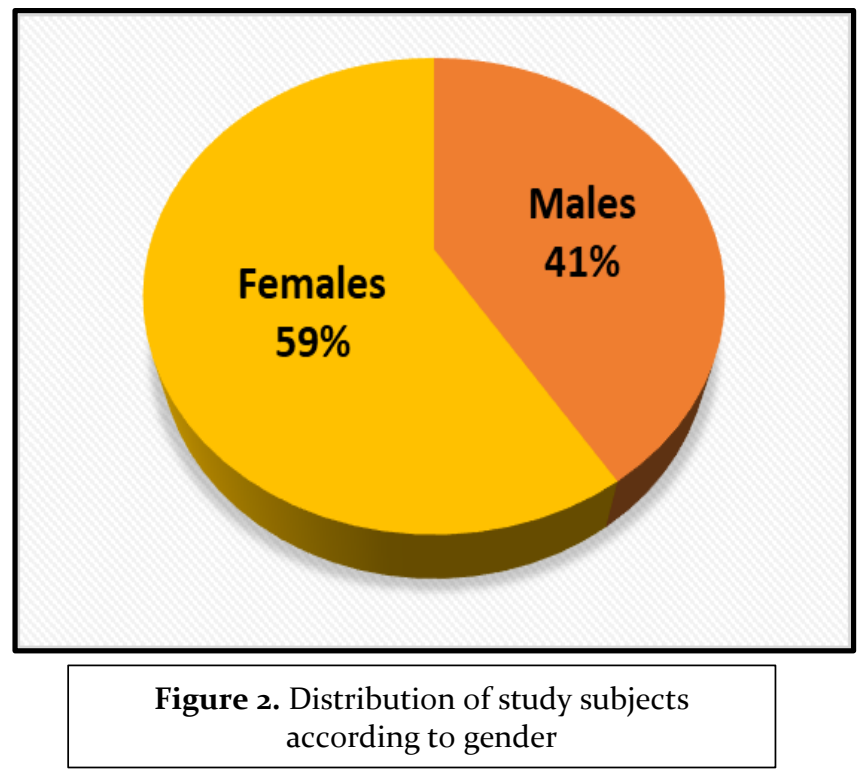

About $65 \%$ (325) and 56\% (280) of the study subjects believed correctly that mouthwash alone will not maintain oral health and chewing gum will not clean their teeth, respectively. When asked about their responses in case of pain in oral cavity, most people $46 \%$ (230) reported they would visit a dentist and major segment of study subjects $56 \%(281)$ believed that there can be more methods for treating oral pain other than the extraction of the tooth itself. When questioned that

"Is it okay to have a decayed tooth if it doesn't cause any pain?", 61\% (305) of the study subjects agreed that it was not okay, also $58 \%$ (292) acknowledged that teeth will not always regrow in place of the extracted decayed teeth and about 62\% (314) of study subjects admitted that extraction of wisdom teeth will not lead to loss of wisdom. Additionally, most of the study subjects, $65 \%$ (326), denied the generally dispersed myths regarding the malalignment of teeth that irregularly placed tooth was fortunate. When questioned about the artificial tooth replacements, $68 \%$ (344) didn't agree with the shared myth that artificial tooth was extracted from another human. Regarding the relationship between the oral health and overall health, 59.6\% (298) were in agreement.

According to the study subjects, the food items causing tooth stains ranged form tea/coffee $(28 \%)$, chocolate $(15 \%)$, beverages $(8 \%)$, banana stem $(5 \%)$, and 


\begin{tabular}{|c|c|c|c|}
\hline QUESTION & RESPONSE & $\mathbf{N}$ & $\%$ \\
\hline \multirow{3}{*}{$\begin{array}{c}\text { Do you think bleeding while brushing is } \\
\text { normal? }\end{array}$} & Yes & 99 & 19.8 \\
\hline & No & 335 & 67 \\
\hline & May be & 66 & 13.2 \\
\hline \multirow{2}{*}{$\begin{array}{l}\text { If your gums are bleeding, will you still brush } \\
\text { your teeth? }\end{array}$} & Yes & 157 & 31.4 \\
\hline & No & 343 & 68.6 \\
\hline \multirow{4}{*}{$\begin{array}{c}\text { Do you think scaling (Tooth Cleaning) will } \\
\text { make your teeth weak? }\end{array}$} & Yes & 116 & 23.2 \\
\hline & No & 204 & 40.8 \\
\hline & May be & 126 & 25.2 \\
\hline & Don't know & 56 & 11.2 \\
\hline \multirow{4}{*}{$\begin{array}{l}\text { Do you think cleaning with salt water or } \\
\text { gargling makes your teeth white or shiny? }\end{array}$} & Yes & 145 & 29 \\
\hline & No & 201 & 40.2 \\
\hline & May be & 119 & 23.8 \\
\hline & Don't know & 35 & 7 \\
\hline \multirow{3}{*}{$\begin{array}{l}\text { Do you think using mouth wash alone is } \\
\text { enough to maintain good oral health? }\end{array}$} & Yes & 137 & $27 \cdot 4$ \\
\hline & No & 325 & 65 \\
\hline & Don't know & 38 & 7.6 \\
\hline \multirow{3}{*}{$\begin{array}{l}\text { Do you think retention of milk tooth } \\
\text { (deciduous tooth) is normal? }\end{array}$} & Yes & 149 & 29.8 \\
\hline & No & 225 & 45 \\
\hline & Don't know & 126 & 25.2 \\
\hline \multirow{4}{*}{$\begin{array}{l}\text { Do you think treating milk tooth is not } \\
\text { necessary as they will exfoliate? }\end{array}$} & Yes & 140 & 28 \\
\hline & No & 171 & 34.2 \\
\hline & May be & 92 & 18.4 \\
\hline & Don't know & 97 & 19.4 \\
\hline \multirow{4}{*}{$\begin{array}{l}\text { Do you think placing the exfoliated upper } \\
\text { deciduous teeth in cow-dung and lower teeth in } \\
\text { roof top will make the permanent tooth to } \\
\text { erupt straight? }\end{array}$} & Yes & 69 & 13.8 \\
\hline & No & 228 & 45.6 \\
\hline & May be & 81 & 16.2 \\
\hline & Don't know & 122 & 24.4 \\
\hline \multirow[t]{4}{*}{ How do you prefer to treat a painful teeth? } & Salt with hot water & 156 & 31.2 \\
\hline & Clove oil & 87 & $17 \cdot 4$ \\
\hline & Camphor & 27 & $5 \cdot 4$ \\
\hline & Visit dentist & 230 & 46 \\
\hline \multirow{4}{*}{$\begin{array}{l}\text { Do you think that any of the following will } \\
\text { reduce pain? }\end{array}$} & Alcohol & 34 & 6.8 \\
\hline & Tobacco & 25 & 5 \\
\hline & Aspirin & 168 & 33.6 \\
\hline & None of the above & 273 & 54.6 \\
\hline \multirow{4}{*}{$\begin{array}{l}\text { Do you think dental treatments are always } \\
\text { painful? }\end{array}$} & Yes & 120 & 24 \\
\hline & No & 202 & 40.4 \\
\hline & May be & 142 & 28.4 \\
\hline & Don't know & 36 & 7.2 \\
\hline \multirow{2}{*}{$\begin{array}{l}\text { Do you think extraction of teeth is the only way } \\
\text { for immediate relief of pain? }\end{array}$} & Yes & 91 & 18.2 \\
\hline & No & 281 & 56.2 \\
\hline
\end{tabular}




\begin{tabular}{|c|c|c|c|}
\hline & May be & 75 & 15 \\
\hline & Don't know & 53 & 10.6 \\
\hline \multirow{4}{*}{$\begin{array}{l}\text { Do you think removal of upper teeth will cause } \\
\text { loss of vision? }\end{array}$} & Yes & 56 & 11.2 \\
\hline & No & 257 & 51.4 \\
\hline & May be & 75 & 15 \\
\hline & Don't know & 112 & 22.4 \\
\hline \multirow{4}{*}{$\begin{array}{l}\text { Do you think teeth lost due to caries / mobility } \\
\text { will lead to short sightedness? }\end{array}$} & Yes & 69 & 13.8 \\
\hline & No & 238 & 47.6 \\
\hline & May be & 65 & 13 \\
\hline & Don't know & 128 & 25.6 \\
\hline \multirow{4}{*}{$\begin{array}{l}\text { Do you think it is okay to have a decayed tooth } \\
\text { if it doesn't cause any pain? }\end{array}$} & Yes & 84 & 16.8 \\
\hline & No & 305 & 61 \\
\hline & May be & 59 & 11.8 \\
\hline & Don't know & 52 & 10.4 \\
\hline \multirow{4}{*}{$\begin{array}{l}\text { Do you think irregularly placed tooth or gap } \\
\text { between teeth is lucky? }\end{array}$} & Yes & 74 & 14.8 \\
\hline & No & 326 & 65.2 \\
\hline & May be & 53 & 10.6 \\
\hline & Don't know & 47 & 9.4 \\
\hline \multirow{4}{*}{$\begin{array}{l}\text { Do you think artificial teeth are natural teeth } \\
\text { that are extracted from another human? }\end{array}$} & Yes & 57 & 11.4 \\
\hline & No & 344 & 68.8 \\
\hline & May be & 40 & 8 \\
\hline & Don't know & 59 & 11.8 \\
\hline \multirow{4}{*}{$\begin{array}{l}\text { Do you think removal of wisdom tooth will lead } \\
\text { to loss of wisdom? }\end{array}$} & Yes & 58 & 11.6 \\
\hline & No & 314 & 62.8 \\
\hline & May be & 47 & 9.4 \\
\hline & Don't know & 81 & 16.2 \\
\hline \multirow{4}{*}{$\begin{array}{l}\text { Do you think all dental treatment during } \\
\text { pregnancy should be avoided? }\end{array}$} & Yes & 212 & 42.4 \\
\hline & No & 102 & 20.4 \\
\hline & May be & 101 & 20.2 \\
\hline & Don't know & 85 & 17 \\
\hline \multirow{4}{*}{$\begin{array}{l}\text { Do you think oral health has relationship with } \\
\text { rest of the body? }\end{array}$} & Yes & 298 & 59.6 \\
\hline & No & 99 & 19.8 \\
\hline & May be & 53 & 10.6 \\
\hline & Don't know & 50 & 10 \\
\hline \multirow{4}{*}{$\begin{array}{l}\text { Do you think chewing gum will clean your } \\
\text { teeth? }\end{array}$} & Yes & 98 & 19.6 \\
\hline & No & 280 & 56 \\
\hline & May be & 91 & 18.2 \\
\hline & Don't know & 31 & 6.2 \\
\hline \multirow{4}{*}{$\begin{array}{l}\text { Do you know that there are two types of } \\
\text { dentition in human beings? }\end{array}$} & Yes & 243 & 48.6 \\
\hline & No & 88 & 17.6 \\
\hline & May be & 55 & 11 \\
\hline & Don't know & 114 & 22.8 \\
\hline \multirow{4}{*}{$\begin{array}{l}\text { Do you think teeth will always regrow in the } \\
\text { place of extracted decayed tooth? }\end{array}$} & Yes & 84 & 16.8 \\
\hline & No & 292 & 58.4 \\
\hline & May be & 69 & 13.8 \\
\hline & Don't know & 55 & 11 \\
\hline
\end{tabular}

Table 1. Responses of study subjects according to their knowledge, awareness and perception of dental myths 
miscellaneous included turmeric, colouring agents, pan chewing, candy etc (table 1).

The belief in myths were compared between male and female study subjects and the findings are as follows: When questioned about whether placing the exfoliated upper deciduous teeth in cow dung and lower teeth in roof top will make the permanent tooth to erupt straight, it was observed that more number of females had answered correctly when compared to males and the difference was significant statistically $(\mathrm{p}=\mathrm{o.00o})$. Also, greater number of females has answered correctly that tooth extraction was not the solitary manner for pain relief when compared to males, and the difference was significant statistically $(\mathrm{p}=0.000)$. Similarly, more number of females believed that removal of wisdom tooth will not lead to forfeiture of wisdom and artificial teeth were not extracted teeth from another human being when compared to males ant it was significant statistically ( $\mathrm{p}=\mathrm{0.000}$, table 2 ).

\section{DISCUSSION}

Twentieth century had an upright revolution in both general and oral health in history. India has a lesser economical resource to meet the over-all population's oral health treatment requirements and this crunch is accompanied by an immense disease burden and a low literacy rate. ${ }^{6}$ Several factors prompt to false belief on oral health care and treatment. This also compels them to learn supplementary means of dismissing pain such as home remedies rather than consulting a professional dentist.7 Paul Broca stated that "the least questioned assumptions are often the most questionable". 8

Many researches and studies were conducted among various population to assess their knowledge and awareness regarding dental myths. Since most of the myths and plenty of misconception stands out more than any other when it comes to oral health. ${ }^{9}$ The present study aimed to assess the acquaintance and mindfulness among the youngsters on numerous dental myths and oral practices which are widespread in India.

In the present study, $40.4 \%$ preferred neem stick for brushing and in the study conducted by Saumyendra V. Singh et al., ${ }^{10,11} 56.7 \%$ of participants preferred the use of datoon or tree twig. The short coming of the neemstick includes gingival trauma and occlusal wear. ${ }^{9}$

According to the current study, only $23.2 \%$ of the subjects reported that scaling will make their teeth feebler with gap formation, scraping /wear of enamel or mobility and it was similar with the earlier study conducted by Kiran et al. ${ }^{5}$ where $24.6 \%$ of their participants perceived similar misconceptions of scaling. In another study done by Harshada Ragunathan et al. ${ }^{12}$ in an out-patient department of a dental college, reported that about $65.9 \%$ of participants responded that professional scaling caused sensitivity which they concluded was due to their lack of awareness. This was in contrast to the present study conducted among the younger population who were more aware about oral hygiene treatment procedures.

The present study displayed $28 \%$ of the subjects believed that the treatment of milk tooth was not necessary as they will exfoliate in the future. Whereas, in a study conducted by Sharma $\mathrm{R}$ et al..$^{13}$ about $58.7 \%$ of their participants and in a study by Yadav $\mathrm{P}$ et al. ${ }^{14}$, $46 \%$ of their subjects felt that treatment of milk tooth was not necessary as they would be replaced by permanent teeth.

For a long time, placement of tobacco was thought to relieve pain and the same was believed for the analgesic effect. But when a question was asked, which of the following will reduce pain, $6.8 \%$ of the participants reported as alcohol, 5.0\% reported as tobacco and $33.6 \%$ reported as aspirin and surprisingly almost $54.6 \%$ of the participants reported as none of the above will actually reduce pain. But in the study conducted by Sharma R et al. ${ }^{13}$ and Raina SA et al. ${ }^{15}$ showed around $49.4 \%$ of their participants believed in the analgesic action of cloves in decayed teeth. It was found that only $17.4 \%$ of the participants in the present study believed the same. The clove oil contains active ingredient eugenol, which helps to numb and reduce pain to ease tooth ache but it was not the permanent solution. Smaller proportion of the population believe that using clove as a permanent solution and did not consider dental treatment as a mandatory option for permanent relief.

In the present study $51.3 \%$ of participants asserted that loss of vision will not occur after the extraction of upper teeth whereas only $11.2 \%$ believed this myth, which is almost similar to the study done by Saravanan $\mathrm{N}$ et al. ${ }^{16}$, where $20 \%$ of their respondents believed in this myth. But it is very much contrast in the study conducted by Gambhir RS et al. ${ }^{17}$, where $72.8 \%$ of participants believed that extraction of upper teeth leads to vision loss. This might be because of the inappropriate local anaesthetic block which may lead 
QUESTIONS

Do you think placing the exfoliated upper deciduous teeth in cow-dung and lower teeth in roof top will make the permanent tooth to erupt straight?

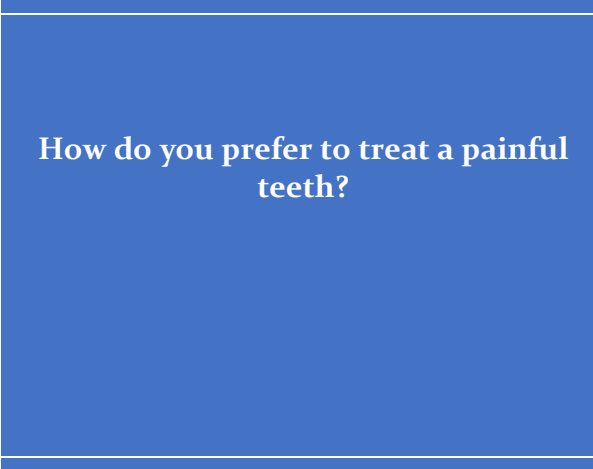

Do you think that any of the following will reduce pain?

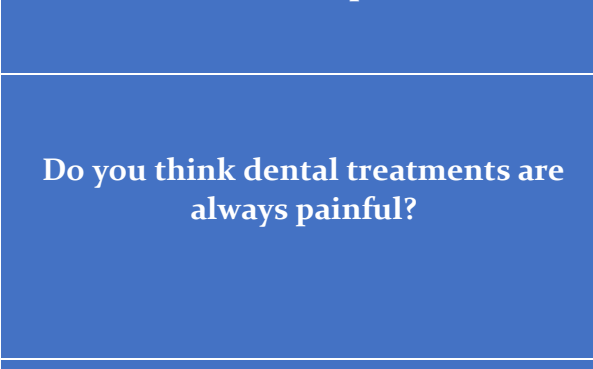

Do you think extraction of teeth is the only way for immediate relief of pain?

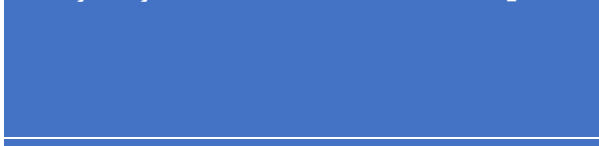

Do you think removal of upper teeth will cause vision loss?

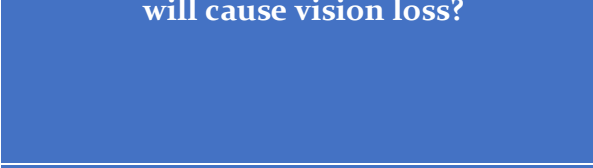

Do you think teeth lost due to caries / mobility will lead to short sightedness?
OPTIONS

MALE

FEMALE

p-value

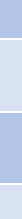

Yes

No

46

78

May be

32

Don't know

49

73

\begin{tabular}{|c|c|c|}
\hline Salt with hot water & 80 & 76 \\
\hline Clove oil & 32 & 55 \\
\hline Camphor & 16 & 11 \\
\hline
\end{tabular}

Visit dentist

77

153

Alcohol

Tobacco

Aspirin

20
17

53

\begin{tabular}{|c|c|}
\hline Alcohol \\
\hline Tobacco \\
\hline Aspirin \\
\hline
\end{tabular}

None of the above

$107 \quad 166$

Yes

32

88

\begin{tabular}{|l|l|}
\hline No \\
May be \\
\hline
\end{tabular}

Don't know

\begin{tabular}{|l|l|}
\hline 84 & 118 \\
\hline 68 & 74 \\
\hline
\end{tabular}

\begin{tabular}{|c|c|c|}
\hline Don't know & 21 & 15 \\
\hline Yes & 50 & 41 \\
\hline No & 91 & 190 \\
\hline May be & 43 & 32 \\
\hline
\end{tabular}

\section{Don't know}

\begin{tabular}{|l|c|}
\hline 21 & 32 \\
\hline 36 & 20 \\
\hline 90 & 167 \\
\hline
\end{tabular}

31

44

\begin{tabular}{|c|c|}
\hline May be \\
\hline Don't know \\
\hline Yes
\end{tabular}

45

64

\begin{tabular}{l|l}
48 & 64
\end{tabular}

\begin{tabular}{|c|c|c|}
\hline Yes & 45 & 24 \\
\hline No & 82 & 156 \\
\hline May be & 24 & 41 \\
\hline Don't know & 54 & 74 \\
\hline
\end{tabular}

0.001

0.000

0.001

0.000

0.001

0.003

(1)

o.ooo

0.000 


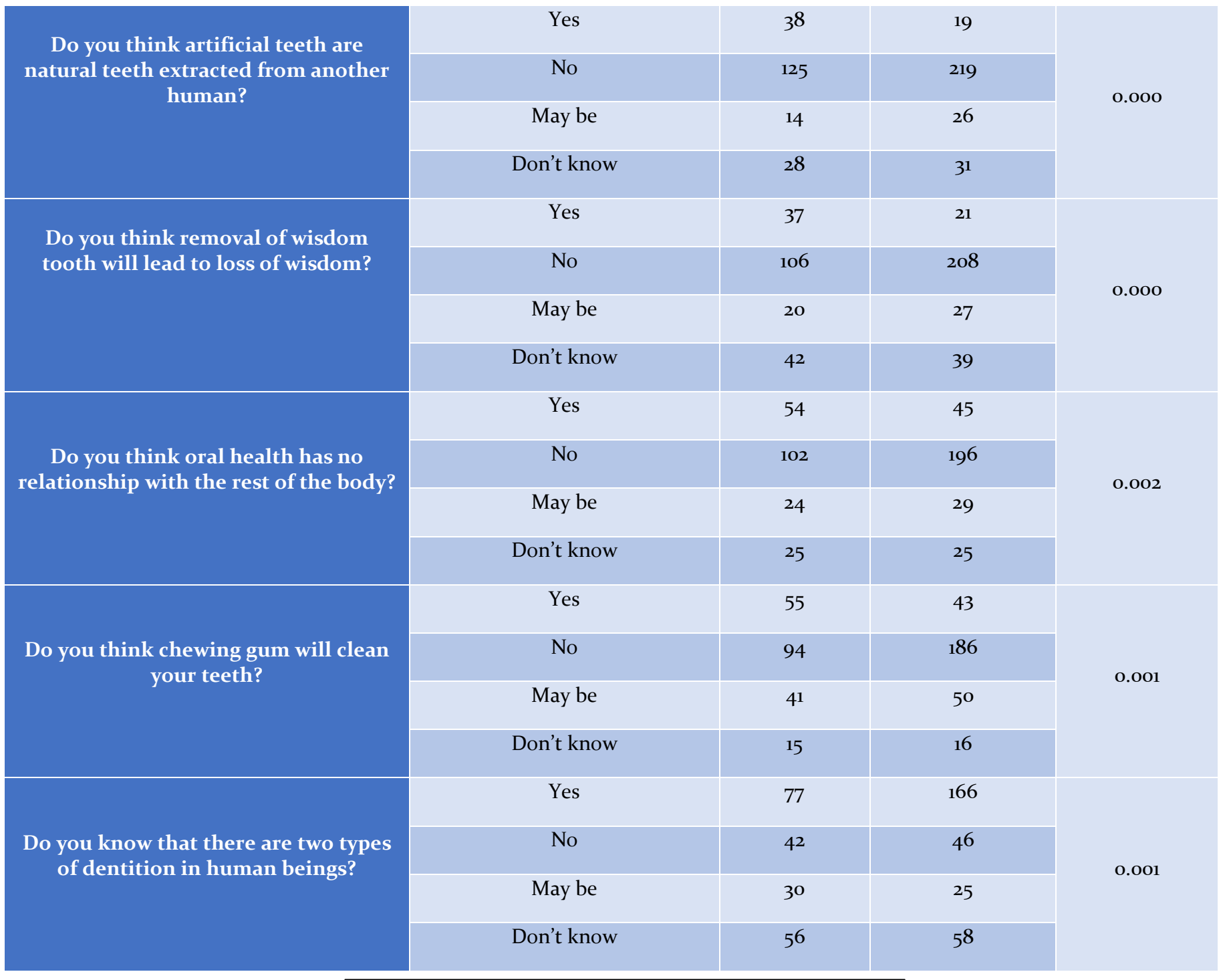

Table 2. Distribution of dental myths based on gender

to minor blurring of vision until the effect of local anaesthesia wears out.

In the present study, $42.4 \%$ participants believed that dental treatments during pregnancy should be avoided. In the study conducted by Vignesh $\mathrm{R}$ et $\mathrm{al} . .^{18}$ about $56.8 \%$ respondents consider that it was better to avoid dental treatment during pregnancy. This shows their lack of knowledge about oral health. ${ }^{19}$ Periodontal diseases in the mother may have harmful effects on the developing foetus. Pregnant women with periodontal diseases are at greater risk of having a pre-term or low birth weight babies and high levels of cariogenic bacteria in mothers can lead to increased dental caries in the infants. Preventive oral health care facilities should be provided during pregnancy. ${ }^{20}$

Dental procedures such as diagnostic radiography, periodontal treatments, restorations and extractions are safe and are best performed during the second trimester. ${ }^{21}$ If examination indicates a need for scaling and root planing or other periodontal treatments, the procedures can be scheduled early in the second trimester. ${ }^{20}$ Because periodontitis has been associated with several poor pregnancy outcomes, although the mechanism remains unclear and the controversy exists. The most common oral disease during pregnancy is gingivitis, as it is aggravated by fluctuations of 
oestrogen and progesterone with changes in oral flora and decreased immune response. ${ }^{21}$ The misconceptions of dental treatments during pregnancy can be overthrown by educating them with proper brushing techniques, flossing and clear communication regrading prevention, treatment and outcomes.

In this study, participants responded that tea, coffee, pan chewing, colouring agents and candies can stain teeth whereas in the study conducted by Priyanka $S$ et al. ${ }^{22}$ declared that cut brinjals could also stain teeth.

In the present study, $56.2 \%$ of the participants denied that extraction was the only treatment to get rid of agony and around $46.0 \%$ preferred to visit a dentist for treating a painful tooth while around $49.5 \%$ of participants in the study conducted by Mythri $\mathrm{H}$ in rural population of Lucknow district believed extraction of teeth was healthier than saving it. ${ }^{23}$ This suggests that the present population had more awareness which might be due to the ease in access to the internet and ease of approach to the private dental care.

On the whole for the most part, it was pleasure to perceive that present young population did not agree to believe much in myths but still smaller proportion of populations did have faith in myths as $14.8 \%$ participants believed that irregularly placed tooth or gap between tooth was lucky while $64.4 \%$ of study population of Emerald SSN et al. ${ }^{24}$ believed that it was lucky. Because of the influence of models and social media about the regularly arranged tooth, younger population desires not to have crooked tooth since it may forbid their level of confidence and charm.

Myths and folklore tales seem like too far, apart from this fast-paced, metropolitan age that we live in. The younger population have access and able to update their knowledge with the availability of technology. Internet is a boon through which one can acquire and recognize how to utilise the cutting-edge technological tools that aids them to clear their misgivings and keeping them updated about information data and news.

Limitation of The Study: The study was conducted only among the younger population of age 18-28. The prevalence of myths might be much greater in the higher age groups.

\section{CONCLUSION}

The questions in the present study were unique and consisted of common myths prevailing in India. The results of this study conclude that the younger population have better knowledge and do not believe in tittle-tattle and desire to be told about others logic than look it up for self. Finest resources to encounter myths is to base out propositions on the best accessible evidence. Evidence based dentistry progress the evidence meritoriously in dental practices. Decrypting the myths by accompanying targeted scientific programmes by the dental health care professionals, non-government and government health organisations to prevent many dental problems and to provide successful treatment. Measures to achieve equal utilisation of dental services and curbing of dental myths at grass root level can be achieved through introducing the basics of oral hygiene as a part of primary education.

Acknowledgement: We like to thank all the participants in the study for their cooperation.

\section{REFERENCES}

1. Joshi S, Garg S, Dhindsa A, Jain N, Singh S. Prevalent Dental Myths and Practices in Indian Population- A Systematic Review. Int Healthc Res J. 2020;3(10):316-26. https://doi.org/10.26440/IHRJ/0310.01314

2. Heglund SP. Dental myths: a deterrent to dental care seeking behaviors in developing countries. Med Case Rep Rev. 2018 1. https://doi.org/10.15761/MCRR.1000115 3. Renu M, Sabhya J, Shameen H, Sindhu P, Vaishnavi D, Anjana AP, et al. Prevalence of Dental MyStud And Misconceptions among the Rural Population of Mangaluru City: A Cross Sectional Study. Austin J Dent. 2018;5(6):1120.

https://doi.org/10.26420/austinjdent.2018.1120

4. Tewari D, Nagesh L, Kumar M. Myths Related to Dentistry in the Rural Population of Bareilly District: A Cross-Sectional Survey. J Dent Sci Oral Rehab 2014;5(2):58-64.

https://doi.org/10.5005/jp-journals-10039-1014

5. Kiran GB, Pachava S, Sanikommu S, Simha BV, Srinivas R, Rao VN. Evaluation of dent-o-myths among adult population Living in a rural region of Andhra Pradesh, India: A cross-sectional study. J NTR Univ Health Sci 2016;5:130-6.

https://doi.org/10.4103/2277-8632.185451 
6. Kinra M, Sharma A, Tiwari A, Todkar, M, Dubey, M. Dental Myth, Fallacies and Misconceptions in Rural Population of Bhopal City: A Cross-sectional Study. Asian Journal of Dental Sciences 2019;1(1):1-7

7. Khan SA, Dawani N, Bilal S. Perceptions and myths regarding oral health care amongst strata of low socio economic community in Karachi, Pakistan. J Pak Med Assoc. 2012 Nov;62(11):1198-203.

8. Kumar S, Mythri H, Kashinath KR. Clinical perspective of myths about oral Health; a hospital based survey. Univ J Pharm. 2014;3:35-7.

9. Brown LJ, Meskin LH. Sociodemographic differences in tooth loss patterns in U.S. employed adults and seniors, 1985-86. Gerodontics1988;4:345-62.

10. Singh SV, Akbar Z, Tripathi A, Chandra S, Tripathi A. Dental myths, oral hygiene methods and nicotine habits in an ageing rural population: An Indian study. Indian J Dent Res 2013;24:242-4.

11. Singh SV, Tripathi A, Akbar Z, Chandra S, Tripathi A. Prevalence of dental myths, oral hygiene methods and tobacco habits in an ageing North Indian rural population. Gerodontology. 2012;29(2):e53-6. https://doi.org/10.1111/j.1741-2358.2010.00395.x.

12. Ragunathan H, Sarumathi T, Aswath N. Myths and dentistry. Drug Invention Today 2029;13(7):1089-92.

13. Sharma R, Mallaiah P, Margabandhu S, Umashankar GK, Verma S. Dental Myth, Fallacies and Misconceptions and its Association with Socio-Dental Impact Locus of Control Scale. Int J Prevent Public Health Sci 2015;1(2):14-20. https://doi.org/10.17354/ijpphs/2015/11

14. Yadav P, Shavi GR, Agarwal M, Choudhary P, Singh D. Myths and Misconceptions about dentistry. A crosssectional study. Arch of dent and Med res. 2015; 1: 14-18 15. Raina SA, Jain PS, Warhadpande MM. Myths and taboos in dentistry. International Journal of Research in
Medical Sciences. 2017; 5: 1936-1942. DOI: http://doi.org/10.18203/2320-6012.ijrms20171821.

16. Saravanan N, Thirineervannan R. Assessment of dental myths among dental patients in Salem city. JIPHD 2011;8(suppl 1);359-63.

17. Gambhir RS, Nirola A, Anand S, GuptaT. Myths regarding oral health among patients visiting a dental school in North India: A cross-sectional survey. Int J Oral Health Sci.2015;5:9-14.

18. Vignesh R, Priyadarshni I. Assessment of the prevalence of myths regarding oral health among general population inMaduravoyal, Chennai. J Educ Ethics Dent. 2012;2:85-91.

19. John JR, Daniel B, Paneerselvam D, Rajendran G. Prevalence of Dental Caries, Oral Hygiene Knowledge, Status, and Practices among Visually Impaired Individuals in Chennai, Tamil Nadu. International Journal of Dentistry 2017:9419648. https://doi.org/10.1155/2017/9419648

20. Task Force on Periodontal Treatment of Pregnant Women, American Academy of Periodontology. American Academy of Periodontology statement regarding periodontal management of the pregnant patient. J Periodontol. 2004;75(3):495.

21. Silk H, Douglass AB, Douglass JM, Silk L. Oral health during pregnancy. Aam Fam Physician 2008;77:1139-45. 22. Priyanka S, Leelavathi L. Myths related to dentistry - An Overview. Drug Invention Today 2018;10(4):350811.

23. Mythri Kumar RS. Perceived myths about oral health in India. Indian J Dent Res. 2015; 26: 333. https://doi.org/10.4103/o970-9290.162882

24. Emerald SSN, Reddy CSV, Rao SN. Dental Health Myths and Misconceptions among Yanadi Tribe of Gonepalli Village, Nellore District, India: A CrossSectional Study. International Journal of Humanities and Social Science Invention 2016; 5(12):9-15.

1. Professor and Head (ORCID ID: https://orcid.org/oooo-0oo3-1385-7647)

2. Professor

3. Junior Resident

Department of Public Health Dentistry, Thai Moogambigai Dental College and Hospital, Chennai, Tamil Nadu, India 